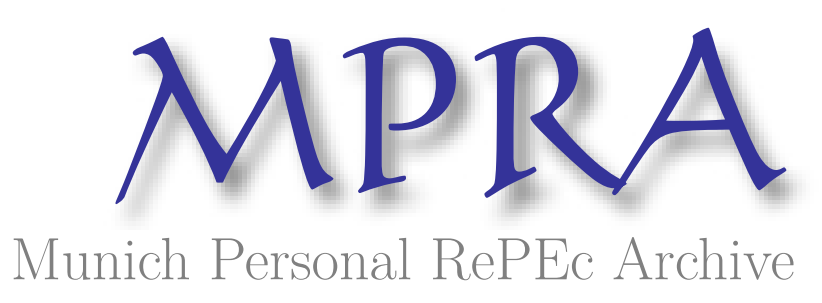

\title{
Dollarization in transition economies: Evidence and policy implications
}

Sahay, Ratna and Vegh, Carlos

September 1995

Online at https://mpra.ub.uni-muenchen.de/20490/

MPRA Paper No. 20490, posted 09 Feb 2010 09:02 UTC 


\section{IMF WORKING PAPER}

(C) 1995 International Monetary Fund
This is a Working Paper and the author(s) would welcome any comments on the present text. Gtations should refer to a Working Paper of the International Monetary Fund, mentioning the author(s), and the date of issuance. The views expressed are those of the author(s) and do not necessarily represent those of the Fund.

WP $/ 95 / 96$

INTERNATIONAL MONETARY FUND

Research Department

Dollarization in Transition Economies:

Evidence and Policy Implications*
Prepared by Ratna Sahay and Carlos A. Vegh

Authorized for distribution by Donald J. Mathieson and Peter Wickham

September 1995

\begin{abstract}
After most restrictions on foreign currency holdings were relaxed in the early 1990s, foreign currency deposits in transition economies have been increasing rapidly. This paper takes a first look at the evidence on dollarization for 15 transition economies, and then discusses some key conceptual and policy implications. Depending on the institutional constraints, foreign currency deposits as a proportion of broad money reached a peak of between 30 and 60 percent in 1992-93. Unlike what has been observed in Latin America, however, dollarization has fallen substantially in the aftermath of successful stabilization plans in Estonia, Lithuania, Mongolia, and Poland. Since foreign currency deposits reflect mainly a portfolio choice, the fall in dollarization can be primarily attributed to higher real returns on domestic-currency assets, as a result of lower inflation and more market-determined interest rates.
\end{abstract}

JEL Classifications Numbers: F41

*This paper was prepared for a volume on Currency substitution and the International Use of Money, edited by Paul Mizen and Eric Pentecost, to be published by Edward Elgar (London). We are grateful to Gerard Bélanger, Dan Citrin, Olivier Frécaut, Vincent Koen, Donald Mathieson, Maria Nieto, Anton Op de Beke, Mark Stone, Luis Valdivieso, Peter Wickham and especially, Russell Kincaid and Miguel Savastano for helpful comments. We are also indebted to all the desk economists who provided us with the data and helped us in interpreting them, and to Ravina Malkani and Manzoor Gill for excellent research assistance. The opinions expressed in the paper are those of the authors and do not necessarily represent those of the International Monetary Fund. 
II. A Conceptual Framework 3

III. Evidence on Dollarization in Transition Economies 7

1. Early reformers with chronic inflation Poland and 8 the former Yugoslavia (then Croatia and Slovenia)

2. Recent reformers with large initial macroeconomic 9 imbalances: Albania, Bulgaria, and Romania

3. Countries with low initial macroeconomic imbalances and low inflation: Hungary, the Czech Republic, and the Slovak Republic

4. High inflation countries of the former Soviet Union:

5. Stabilization with de-dollarization: the Baltic Republics and Mongolia

IV. Policy Implications

1. The importance of institutional factors 13

2. Dollarization and real rates of return 14

3. Monetary policy in a highly dollarized economy 22

4. Should dollarization be resisted? 23

$\begin{array}{lr}\text { v. Conelusion } & 24\end{array}$

Text Tables:

1. .Estonia-Deposit Rates, 1991-94 18

2. Lithuania-Deposit Rates, 1991-94 19

3. Mongolia--Deposit Rates, 1991-94 20

4. Poland-Deposit Rates, 1987-94 21

Figures:

1. Selected Transition Economies: Dollarization and Inflation 10a

2. Selected Transition Economies: Dollarization and Inflation 10b

$\begin{array}{lr}\text { References } & 26\end{array}$ 
Summary

As has been observed in many high-inflation market economies, the use of foreign currencies (currency substitution) has been on the rise in the economies in transition in recent years. This phenomenon raises concerns regarding: (i) policymakers' ability to conduct monetary and exchange rate policy effectively; and (ii) the inflationary consequences of a lower stock of real domestic money. Such issues are particularly worrisome in those transition economies where budget deficits are large and the instruments of monetary control are poorly developed. The economies in transition also provide a unique opportunity to undertake a comparative analysis of how large-scale institutional changes and a rapidly evolving macroeconomic environment affect currency substitution.

This paper documents the extent and evolution of dollarization in 15 economies in transition between 1990 and 1994. Preliminary evidence suggests that with the advent of radical market reforms since the early 1990s, deposits in the domestic banking system denominated in foreign currencies have generally risen very rapidly. This dollarization process, however, has varied considerably across countries. Furthermore, unlike what has been observed in several Latin American countries, dollarization appears to have abated in those transition economies where inflation has been brought under control.

In the light of the empirical evidence, the paper uses a conceptual framework to discuss several policy issues related to the dollarization process: (i) the importance of institutional factors; (ii) the role of real rates of return; (iii) the impact of dollarization on monetary policy; and (iv) whether dollarization should be actively discouraged. 



\section{Introduction}

High and variable inflation severely hinders the ability of national currencies to function efficiently as a store of value, a unit of account, and a means of exchange. As a result, in high inflation countries the domestic currency tends to be gradually displaced in favor of a stable currency (usually, but not always, the American dollar). In the absence of foreign exchange restrictions, casual evidence suggests that such a process begins by the foreign currency replacing the domestic currency as a store of value. In effect, in many high inflation countries, the store-of-value function of domestic money has virtually disappeared, as the public holds most of its financial savings in the form of foreign currency-denominated time deposits. As high inflation continues, many prices (especially real estate and durable goods) begin to be quoted in a foreign currency. Prolonged periods of high inflation may also induce the public to carry out many transactions--especially those involving big-ticket items--in foreign currency.

The phenomenon just described has been generally referred to as currency substitution or dollarization. 1/ Dollarization has been pervasive in many high inflation developing countries, particularly in Latin America (see Savastano, 1992). 2/ Typically, foreign currency deposits were not allowed in Latin American countries until the mid-1970s. However, once financial and exchange rate restrictions were lifted, a gradual but sustained dollarization process took place. Thus, as of 1993, the dollarization ratio (the ratio of foreign currency deposits to broad money inclusive of foreign currency deposits) varies from nearly 80 percent in Bolivia to 70 percent in Uruguay and 70 percent in Peru. Furthermore, these economies have remained highly dollarized even when inflation has fallen substantially, reflecting the irreversible effects of prolonged periods of macroeconomic instability and financial innovation. Widespread dollarization has posed formidable challenges to policymakers by hindering monetary control and worsening the inflationary consequences of financing budget deficits with money creation.

1/ The terminology used in the literature is rather confusing, as emphasized by Giovannini and Turtelboom (1994). In this paper, we follow Calvo and Végh (1992) and define "dollarization" as the phenomenon of using a foreign currency as a store of value, a unit of account, and a medium of exchange, and "currency substitution" as the use of a foreign currency as medium of exchange. These concepts will be illustrated in Section II with the help of a theoretical model.

2/ Evidence of dollarization has also been documented for Israel, Lebanon, Turkey, and some Middle Eastern, Asian, and African countries (see, for example, El-Erian (1988), Bufman and Leiderman (1993), Mueller (1994), and Agénor and Khan (1994)). 
The attractiveness of a stable foreign currency has certainly not been confined to market economies. During the 1980s, rising inflation led to widespread dollarization in both Poland and the former Yugoslavia and, by the end of the decade, the dollarization ratio had reached 70 to 80 percent in both countries. In the typical soviet-style planned economy, however, foreign currency holdings by domestic residents were strictly prohibited. IJ Moreover, foreign exchange for international transactions would be centrally-allocated and all international trade would be conducted through specialized institutions (often referred to as "foreign trade organizations").

With the advent of radical market reforms in the formerly-planned economies during the early 1990s, restrictions on foreign currency holdings were lifted to varying degrees as part of comprehensive packages of financial liberalization. As a result, foreign currency deposits in the transition economies have increased quite rapidly since the market reforms started. This paper examines the evidence on dollarization for 15 economies in transition (nine Central and Eastern European countries, five former republics of the Soviet Union and Mongolia). 1/ This is not only of interest in itself--given the important macroeconomic implications of dollarization--but also offers a rare opportunity to revisit many important conceptual and policy issues related to currency substitution and dollarization in light of this substantial new body of evidence.

The evidence examined shows that dollarization quickly reached significant levels in several transition economies. Depending on the institutional constraints, the dollarization ratio has varied from 0 to 10 percent at the start of the reform programs (with the exception of Poland and the former Yugoslavia noted above) to a peak of 30-60 percent in most countries in 1992-93. While partly reflecting a stock adjustment, dollarization has acquired particular importance in those economies--such as Romania and Russia--where the combination of high inflation rates and widespread regulations on interest rates rendered real returns on domesticcurrency-denominated assets quite unattractive. The evidence also shows that, unlike what has been observed in Latin America, dollarization has fallen substantially in the aftermath of successful stabilization plans in Estonia, Lithuania, Mongolia, and Poland.

The paper proceeds as follows. Section II uses a simple model to clarify the concepts of dollarization and currency substitution. Section III examines the evidence on dollarization in 15 economies in transition. In light of the evidence, Section IV discusses several conceptual policy

1/ Cuba recently relaxed some of the restrictions on foreign currency holdings in an effort to attract hard currency, but the policy appears to have been reversed (see Pérez, 1994).

2/ It should be noted that the quality of some of the data is uncertain, in particular for Russia. Hence, the figures shown in this paper should be viewed as indicating rough order of magnitudes rather than exact levels. 
issues related to the dollarization process: (i) the importance of institutional factors; (ii) the role of real rates of return; (iii) the impact of dollarization on monetary policy; and (iv) whether dollarization should be actively discouraged or not. Section $v$ contains concluding remarks.

\section{A Conceptual Framework}

As mentioned in the Introduction, the concepts and terminology underlying the currency substitution/dollarization literature are rather confusing, since the same terms are often used interchangeably to refer to essentially different phenomena. To clarify these ideas and set the stage for presenting the evidence and deriving policy implications in subsequent sections, this section briefly reviews a model which makes transparent the different concepts involved. $1 /$

Consider a one-good world in which consumers may hold four assets: domestic currency, foreign currency, domestic bonds, and foreign bonds. Domestic bonds are denominated in domestic currency, while foreign bonds are denominated in foreign currency. Since currencies do not bear interest, consumers will hold them only if they provide some liquidity services. Hence, it is assumed that real domestic money balances (m) and real foreign currency balances (f) reduce transactions costs. Specifically, transactions costs are given by a transactions technology of the form: $1 /$

$$
s=\operatorname{cv}(\mathrm{M}, £), \quad v>0, v i<0, v 2 \wedge 0, v] i>0, v 22>0, v i 2>0,{ }^{v} 11^{v} 22 \|^{v} i s^{>0} \gg
$$

where $\mathbf{s}$ is shopping time and $\mathrm{c}$ is real consumption. Thus, additional real money balances (either domestic or foreign) bring about positive but

1/ The model below is due to Thomas (1985). The reader is referred to Thomas's paper for analytical details and to Calvo and Végh (1995b) for a detailed discussion of the conceptual implications of using Thomas's framework.

2/ Transactions costs are viewed as real resources spent in transacting, as in Thomas (1985). An alternative specification would assume that consumers value leisure and that time is needed to transact, as in végh (1989). The two scenarios are equivalent for the issues being discussed here. For expositional simplicity, and without loss of generality, it has been assumed that transactions costs are homogeneous of degree one in $c, m$, and $f$, as in végh (1989). Since this is a static model, time subscripts are omitted for simplicity. 
diminishing reductions in transactions costs. 1/ The convexity of the transactions costs technology will ensure, that well-behaved money demand functions follow from (1).

Bonds do not provide liquidity services and are thus only held as a store of value. To introduce imperfect substitution between domestic and foreign bonds, Thomas (1985) assumes that the domestic and the foreign price levels evolve stochastically, according to different wiener processes.

Hence, for given nominal returns, real returns on domestic and foreign bonds are uncertain.

The consumer's preferences are characterized by a Von NeumannMorgenstern utility function, which is increasing and strictly concave in c. Let $6 A(j-m, f, b$, and $d)$ denote the share of asset $j$ in total financial wealth, $m+f+d+b$, where d denotes real holdings of domestic bonds and $b$ real holdings of foreign bonds. Naturally, $g_{m}+0_{f}+0_{d}+0_{b}-1$. The consumer's problem consists in optimally choosing consumption and the portfolio structure $\left(0_{m}, 0_{f}, 0_{d}, O_{b}\right)$. Thus, $B f+0_{b}$ denotes the fraction of (net) financial wealth denominated in foreign currency. First-order conditions are given by (see Thomas (1985)):

$$
\begin{aligned}
& -v_{1}\left(\frac{m}{c}, \frac{f}{c}\right)=i \\
& -v_{2}\left(\frac{m}{c}, \frac{f}{c}\right)=i * \\
& 9_{f}+\theta_{b}=[1 *-(1-\epsilon)] \Gamma,
\end{aligned}
$$

where $r$ denotes a term involving variability of returns and the degree of relative risk aversion, $i$ and $i *$ are the domestic and foreign nominal interest rates, respectively, and $c$ is the domestic rate of devaluation. Equations (2) and (3) implicitly define the money demand functions (see Végh, 1989):

1/ Note that the transactions costs technology specified in (1) assumes that both currencies are imperfect substitutes. Imperfect substitution could be derived endogenously by assuming that there are costs associated with transacting in foreign currency (see sturzenegger (1993)). 
$\begin{array}{ll}m=c L^{m}\left(i, i^{*}\right), & L f<0, L_{1}>, \\ \mathbf{f}-\mathrm{c} \mathrm{I}^{\mathrm{f}}\left(i, i^{*}\right), & \mathrm{L}^{\wedge}>0, \mathrm{~L}_{i^{\circ}}^{\mathrm{f}}<0,\end{array}$

where the partial derivatives follow from the properties of the transactions costs technology given in (1).

Several key observations follow from equations (4), (5), and (6). First, note that (5) and (6) imply a relative money demand of the form:

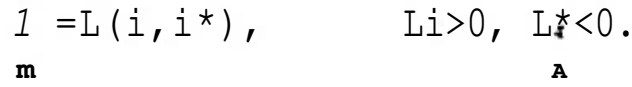

Therefore, an increase in $i$ increases the ratio of foreign money to domestic money, as in the early currency substitution models a la Calvo and Rodriguez (1977). This is how currency substitution should be understood: the demand for foreign currency (as a means of exchange) relative to domestic currency depends on the opportunity cost of both currencies (i.e., the domestic and foreign nominal interest rates). 1/

The second key observation, which follows from (4), is that the consumer's optimal choice of total foreign currency-denominated assets (i.e., $0 f+0^{\wedge}$ ) depends only on the real return differential, $i *-(i-\epsilon)$ (in addition to risks considerations and the degree of risk aversion). 1/ In particular, it does not depend on nominal returns or on the liquidity services provided by currencies. We take $\$ \notin+0^{\wedge}$ to represent the degree of dollarization (i.e., the share of financial assets denominated in the foreign currency). Other things being equal, dollarization (i.e., $\left.8 f+\theta_{b}\right)$ depends negatively on $i$ (as follows from equation (4)), reflecting higher real returns on domestic-currency denominated assets. It should be

1/ In early models of currency substitution a la Calvo-Rodriguez, foreign currency and domestic currency were assumed to be the only assets. Hence, an equation such as (7) was enough to describe the financial side of the economy.

2/ By definition, the real return differential between foreign-currency and domestic-currency denominated bonds is $1 *-\# r^{\star}-(i-w)--w h e r e * \star$ and * denote foreign and domestic inflation, respectively. In this single-good world where the law of one price holds (i.e, $\left.n-e+w^{*}\right)$ ), the real return differential simplifies to $i *-(i-e)$. 
emphasized that, under this definition, dollarization captures the use of a foreign currency both as a means of exchange and as a store of value. and is therefore a broader concept than currency substitution.

The consumer thus decides on his or her currency holdings based on the transactions services that they provide and then borrows and lends to achieve the optimal portfolio dictated by (4). The separation of currency and asset demands results from the general property of financial markets that allows consumers to separate claims on assets from the trading of services of these assets. To see this, consider a reduction in $i$, accompanied by one-to-one decrease in $c$, so that $i-\epsilon$ and thus $i *$ ( $i-e)$ do not change. Then, the consumer wishes to hold additional real domestic money balances and less foreign currency for transactions motives (as follows from (5) and (6)), but does not wish to change the composition of his or her financial portfolio since the real return differential, $i *-(i-e)$, did not change. To this end, the consumer simply borrows the desired "pesos" (by issuing a domestic-currency liability) and lends the undesired "dollars" (by buying a foreign-currency denominated asset), which leaves unchanged his or her total dollar portfolio because foreign-currency denominated assets and liabilities increase by the same amount. Then, as a result of the fall in $i$ (and $e$ ), currency substitution would decrease but dollarization would remain unchanged.

With this model at hand, it is easy to how confusion may arise. Conceptually, if the terms currency substitution and dollarization are used interchangeably (as they often are), then there is no distinction being made between the phenomenon captured in (4) (dollarization or asset substitution) and that captured in (7) (currency substitution). This can be misleading since both the determinants and conceptual implications of the two phenomena are rather different. 1/ Empirically, suppose that one has the phenomenon of currency substitution in mind, as captured in equation (7). In that case, one would be looking for a positive relationship between $i$ and $f / m$. However, due to the absence of data on foreign currency in circulation, $0^{\wedge}$ (as represented, in practice, by the share of interest-bearing foreign currency deposits) has been typically used in econometric studies as a proxy for $f$ in equation (7). If such an equation were to be estimated, it would

1/ Note that there could be dollarization with no currency substitution (i.e, 6f-0), which would be the case if the transactions technology (1) did not have $f / c$ as an argument. Americans, for example, do not hold Deutsche marks to carry out domestic transactions, but may very well hold German bonds. In such a case, dollarization is undistinguishable from the phenomenon of capital mobility. In theory, at least, there could also be currency substitution (I.e., of $>0$ ) with no dollarization (i.e, $0 f+\$ \wedge-$ $0)$. This would be a situation in which consumers borrow the dollar bills that they need to transact, so that their net foreign asset position is zero. This latter scenario, however, is not likely to arise in practice. 
be misspecified because $6^{\wedge}$ is affected by real returns and not by nominal returns. $1 /$

Finally, it is important to point out that while the sharp distinction between liquid and non-liquid assets (i.e., between money and bonds) is very useful for conceptual purposes, in practice there is likely to be a continuum of assets with various degrees of liquidity. Analytically, this could be captured by introducing interest-bearing liquid assets, along the lines of Calvo and Végh (1995a). The basic insights of the model should remain unchanged, with the demand for liquid financial assets depending on the opportunity cost (given by the interest rate differential vis-a-vis the non-liquid asset) and the degree of liquidity services that they provide.

III. Evidence on Dollarization in Transition Economies

This section presents evidence on dollarization in 15 economies in transition: nine Eastern European countries (Albania, Bulgaria, Croatia, the Czech Republic, Hungary, Poland, Romania, the Slovak Republic, and Slovenia) five former republics of the Soviet Union (Estonia, Latvia, Lithuania, Russia, and Ukraine), and Mongolia. The period covered for most countries begins at the start of the large-scale reform programs (1990-92) and ends in 1993-94. The measure of dollarization that will be reported (referred to as the "dollarization ratio") is the ratio of foreign currency deposits in the domestic banking system to broad money (normally M2) including foreign currency deposits. 2/ Subject to data availability, countries were chosen so as to have as diverse a sample as possible in terms of the macroeconomic and institutional environments. Such diversity should prove quite useful in evaluating the origins, dynamics, and implications of the dollarization process in transition economies.

In examining the evidence, countries that share some key characteristics will be grouped together to highlight key features or puzzles of the dollarization process in transition economies. These groups are: (1) early reformers with chronic inflation (Poland and countries of the former Yugoslavia), (2) recent reformers with large initial macroeconomic imbalances (Albania, Bulgaria, and Romania), (3) reformers with low initial

1/ While It is virtually impossible to measure the exact degree of currency substitution, it appears to be much less pervasive than dollarization since the domestic currency usually continues to be widely used for daily transactions. In fact, Sachs (1986) claims that, even at the height of the Bolivian hyperinflation, dollars were rarely used as a means of exchange.

2/ Note that this measure varies between 0 and 100 percent. The share of foreign-currency deposits in the domestic banking system is an imperfect measure of dollarization (as defined in the model of Section II) for three main reasons: (i) of cannot be measured; (ii) 0^ should also include foreign-currency denominated assets held abroad; and (iii) 0^ should not include deposits of non-residents. 
macroeconomic imbalances and low inflation (Hungary, the Czech Republic and the Slovak Republic, (4) high inflation countries of the former Soviet Union (Russia and Ukraine), and (5) successful reformers with de-dollarization (the Baltic Republics and Mongolia).

1. Early reformers with chronic inflation Poland and the former Yugoslavia (then Croatia and Slovenia)

During the 1980s, Poland and the former Yugoslavia initiated their market-oriented reforms, which included the relaxation of restrictions on foreign currency holdings. At the same time, chronic inflation, fueled by accommodative monetary and exchange rate policies and sustained by formal and informal indexation, led to increasing dollarization. In fact, the pre-reform inflationary experience of both Poland and the former Yugoslavia is in many ways reminiscent of that in Latin American countries (see Kiguel and Liviatan, 1991).

In early 1990, both countries embarked on exchange rate-based stabilization programs, which brought about a dramatic initial fall in inflation. By 1993, Poland had reduced the inflation rate to very low levels. Furthermore, by making domestic currency deposits more attractive, it has succeeded in reducing the dollarization of the economy to levels prevailing in the mid-1980s (Figure 1). In sharp contrast, inflation in the former Yugoslavia quickly resumed and dollarization ratios reached the 70-90 percent range during the late 1980s. In fact, during the high inflation period of the late 1980s, foreign currency deposits were the only bank accounts that earned positive returns in real terms.

Following the dissolution of the former Yugoslavia, Croatia continued to experience high inflation rates, with quarterly inflation peaking at 120 percent during the last quarter of 1992 and the dollarization ratio surpassing 80 percent (Figure 1). 1/ Slovenia, on the other hand, succeeded in rapidly reducing inflation from over 60 percent in the last quarter of 1991 to less than 5 percent in the first quarter of 1994 . The dollarization ratio, however, remained stable at around 45 percent throughout this period (Figure 1). Since late 1993, Croatia also succeeded in drastically reducing inflation but without any discernable effect on the dollarization ratio (as of early 1994).

One institutional reason for the observed high levels of foreign currency deposits in both Croatia and Slovenia during 1992-93 is the governments' decision to temporarily freeze part of these deposits and

IJ The dollarization ratio for Croatia in Figure 1 is somewhat lower than that reported in the text as the figure excludes frozen deposits. 
permit access to them only gradually over time. I/ Also, the high dollarization ratio in slovenia may be biased upwards to the extent that, as is believed, a significant fraction of the deposits belongs to non-residents from neighboring high inflation countries.

\section{Recent reformers with large initial macroeconomic} imbalances: Albania. Bulgaria and Romania

Open inflation is a relatively new phenomenon in Albania. Bulgaria, and Romania. 2/ All three countries inherited large macroeconomic imbalances and faced an adverse external environment at the start of their reform programs (reforms started in early 1991 in Bulgaria and Romania, and in mid-1992 in Albania). Before the advent of reforms, prices were rigidly controlled even as demand rose and output declined. The immediate consequence of freeing prices was thus a substantial price increase during the first year of reforms. Inflation remained relatively high during 1992-93, except in Albania where the monthly rate began to decline in 1993. In all three countries, inflation was sustained through monetary financing of large budget deficits, de facto nominal wage indexation, and a build up of interenterprise arrears.

As was typical in planned economies, foreign currency holdings in the pre-reform period were strictly prohibited. Restrictions on foreign currency deposits for residents, non-residents, and enterprises were removed as part of the early financial sector reforms. Not surprisingly, the dollarization ratio in all three countries experienced a sharp jump after regulations on foreign currency holdings were relaxed. In Albania, the dollarization ratio quickly reached 20 percent and seems to have leveled off at 20-25 percent following the rapid fall in inflation in 1993-94

(Figure 1). In Bulgaria and Romania, the dollarization ratio rose rapidly in the midst of failed attempts to end inflation, reaching higher levels than In Albania (Figure 2). By the end of 1994, the dollarization ratio in Bulgaria and Romania stood between 20 and 30 percent.

3. Countries with low initial macroeconomic imbalances and low inflation; Hungary, the Czech Republic, and the Slovak Republic

of all transition economies in the sample, Hungary was the closest to a market economy at the beginning of the 1990s (see Boote and Somogyi (1991)). Starting in the late 1960s, Hungary had gradually introduced market-oriented reforms. The pace of reforms accelerated in 1990-91 when energy and food

1/ Before the break-up, the National Bank of Yugoslavia had guaranteed households' foreign currency deposits. At the time of the break-up, the Croatian and slovenian governments decided to freeze these deposits because they had very little foreign exchange to meet their demand had there been large-scale withdrawals from banks.

1/ On Romania, see Demekas and Khan (1991); on Albania, see Blejer et al (1992). 
prices were freed, the forint was devalued, and subsidies were reduced. As a result of these corrective measures, annual inflation rates increased from less than 20 percent to over 30 percent in 1990-91. While the macroeconomic performance in 1992-93 was mixed (stagnant or declining output and widening budget deficits partly due to expenditures related to structural reforms), annual inflation was reduced to close to 20 percent.

As part of the gradual reforms introduced in Hungary, resident and nonresident households were allowed to hold foreign currency deposits in local commercial banks starting in 1988. Enterprises (except for some transactions in joint ventures), however, were not permitted to open foreign currency accounts. In July 1989, commercial banks were authorized to extend credit in foreign currency to the domestic enterprise sector. Since 1989, household's foreign currency deposits began to increase rapidly as their source was not required to be reported. The dollarization ratio increased from less than 5 percent in December 1989 to over 15 percent in September 1991, and has stabilized since then (Figure 1). The levelling off of the ratio since September 1991 is most likely related to the narrowing of the return differential between forint and dollar deposits and the decline in inflation.

During the planning era, the former Czechoslovakia was a tightly controlled but prudently managed economy. The implementation of an ambitious market-oriented reform program in early 1991 went hand-in-hand with the continuation of stable macroeconomic policies. As a result, and despite the disruptive break-up of the country in 1992-93, both the Czech and Slovak Republic are among the more advanced and well-managed transition economies (see Aghevli, Borensztein, and van der Willigen (1992)). Both residents and non-residents have been allowed to hold foreign currency deposits since the reforms began. I $J$ The dollarization ratio in the former Czechoslovakia was only about 10-12 percent at the time of the breakup, with a lower ratio in the slovak Republic than in the Czech Republic (Figure 1). As inflation continues at low levels, dollarization ratios have remained roughly unchanged. Furthermore, since the latter half of 1993, domestic interest rates in the Czech Republic have been rising relative to returns on foreign currency deposits.

4. High inflation countries of the former Soviet Union: Russia and Ukraine

Under the auspices of "glasnost" and "perestroika," a limited number of piecemeal reforms were introduced in the former soviet Union during 1985-90. These reforms were mainly confined to increasing the autonomy of state enterprises without hardening their budget constraints or freeing prices. The result was a rapid deterioration in the fiscal accounts which

1/ Some existing restrictions are not likely to be binding with the exception of, like in many other countries, surrender requirements on exports. 
$-10 \mathrm{a}-$

Figure 1. Selected Transition Economies: Dollarization and Inflation 1/

- - - - Dollarisatlon ratio (left scale) Hungary
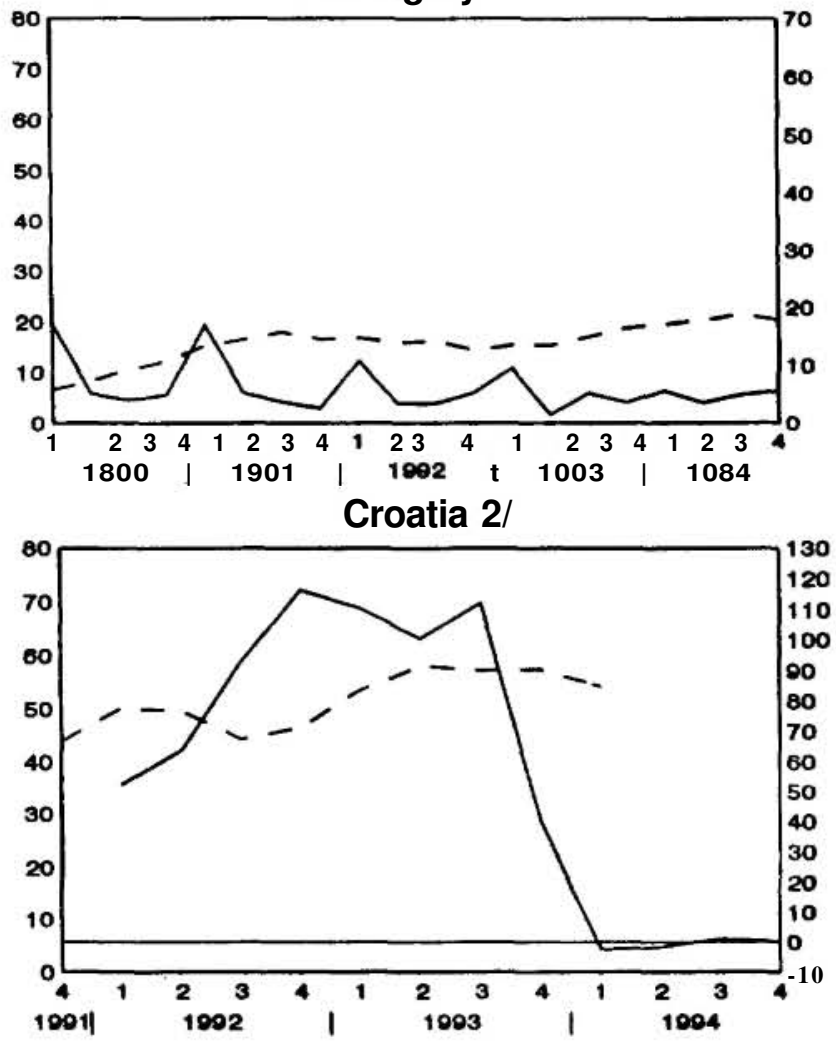

Czech Republic

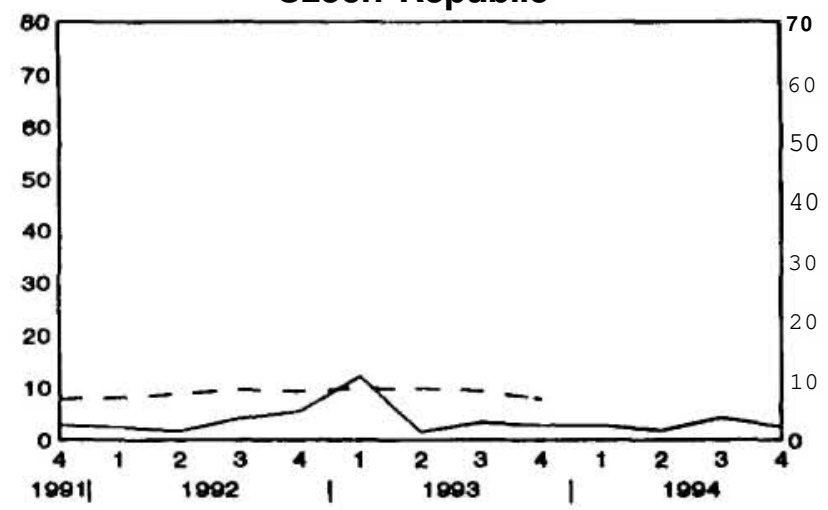

Albania

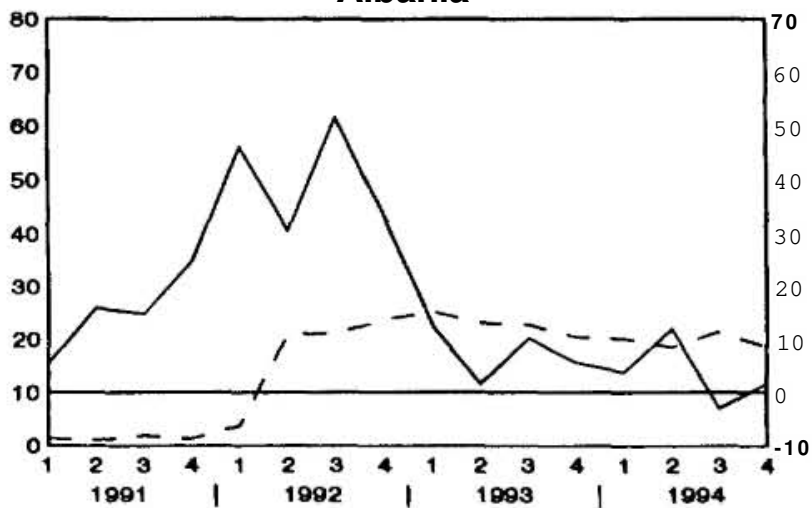

Inflation (in percent a quarter, end-of-period: right icale) Poland

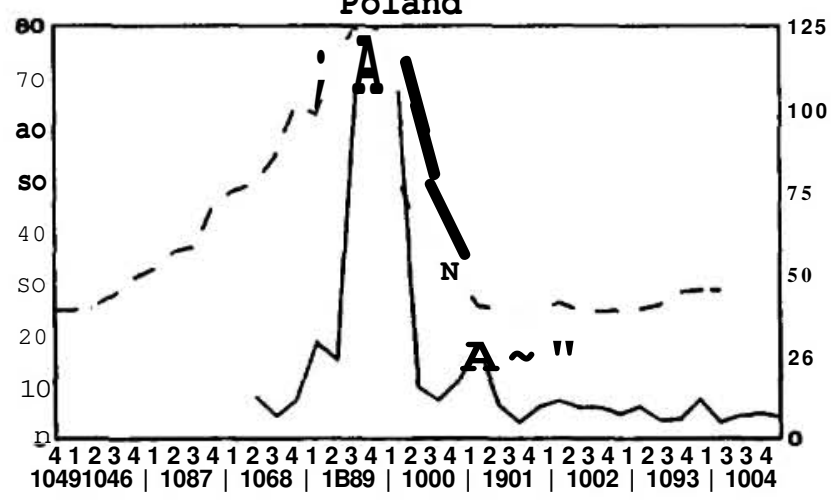

Slovenia

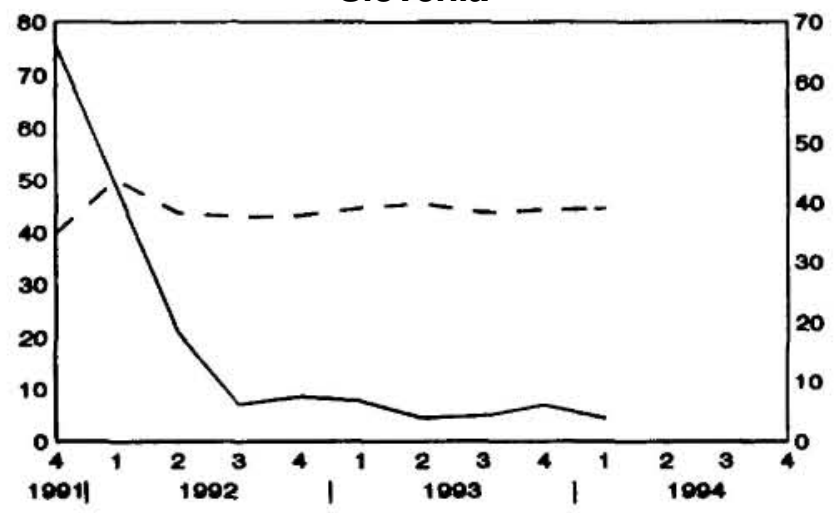

Slovak Republic

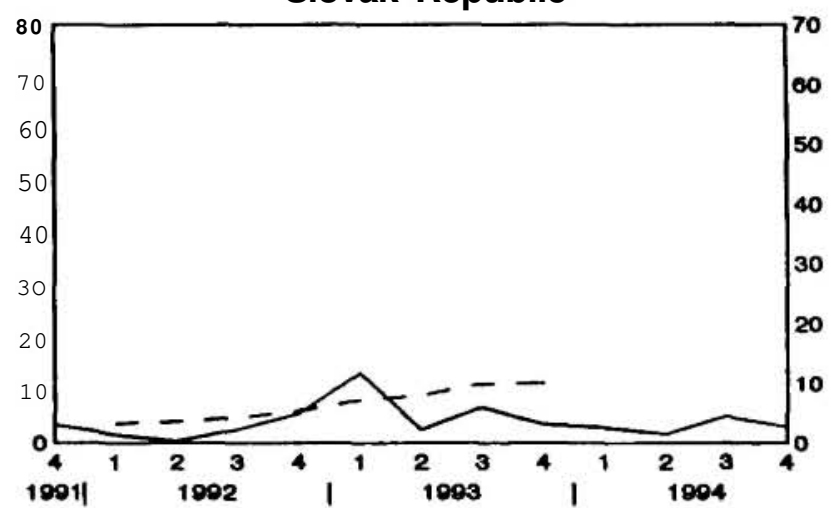

\section{Lithuania}

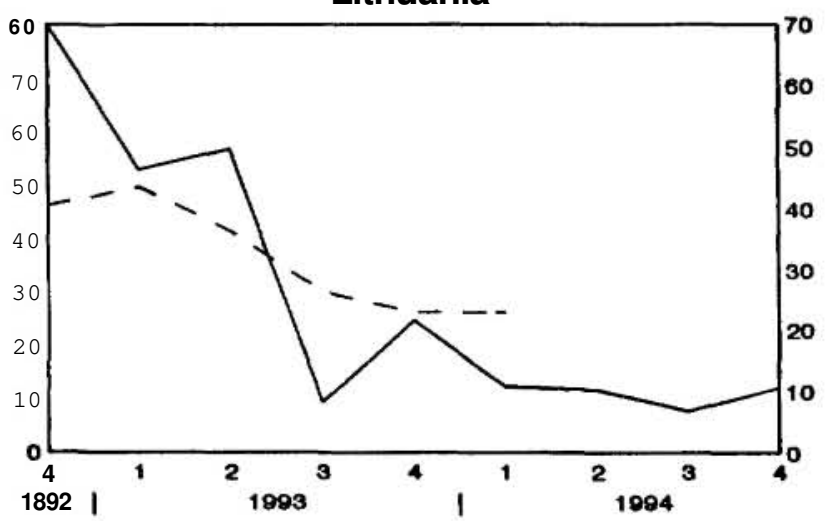

1/ Dolltrizalion it menurtd by the ratio of foreign currency deposit! to broad money (including foreign currency depotiti). Note that the ioNilioQ icilei differ for Albanit, Crottii in* Po!ia4. 
- $10 b$ -

Figure 2. Selected Transition Economies: Doliarization and Inflation 1/

-- Dollariiation ratio $0 \ll \mathrm{ft}$ ac*1c)

\section{Bulgaria}

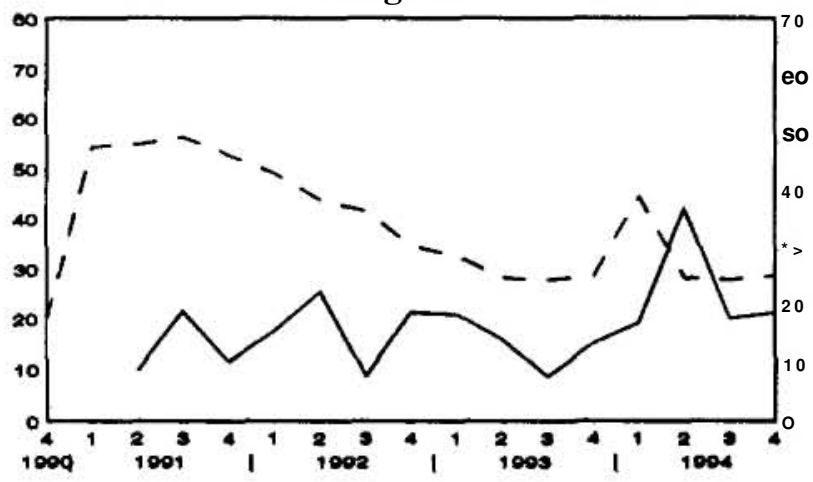

Estonia

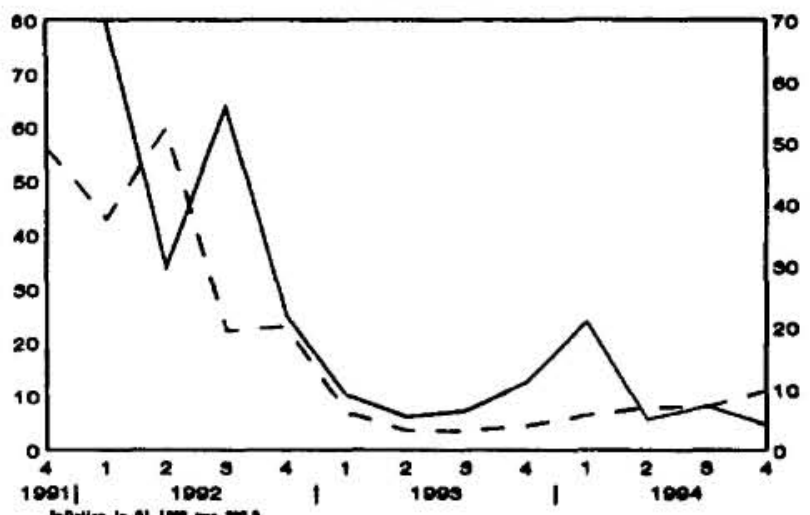

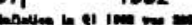

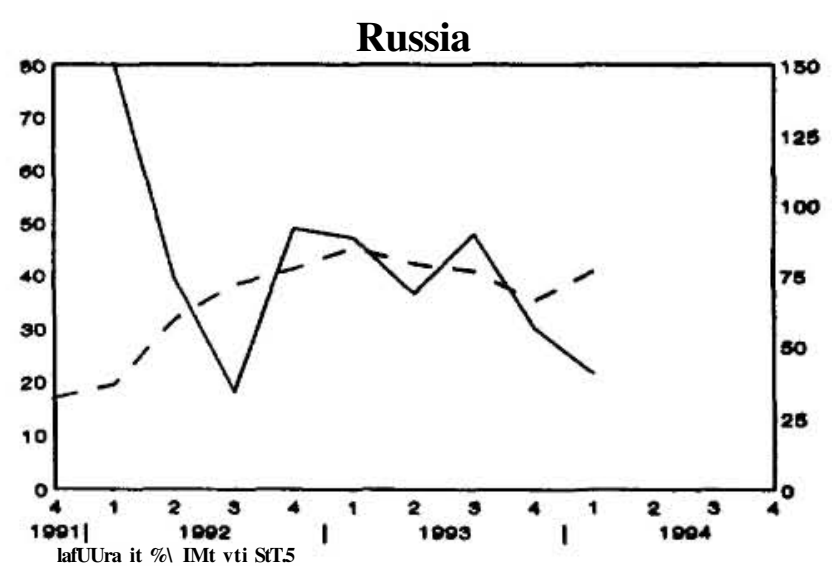

lafUUra it \% IMt vti STT5
Inflation (in percent a quarter, end-of-period; right scale)

Romania

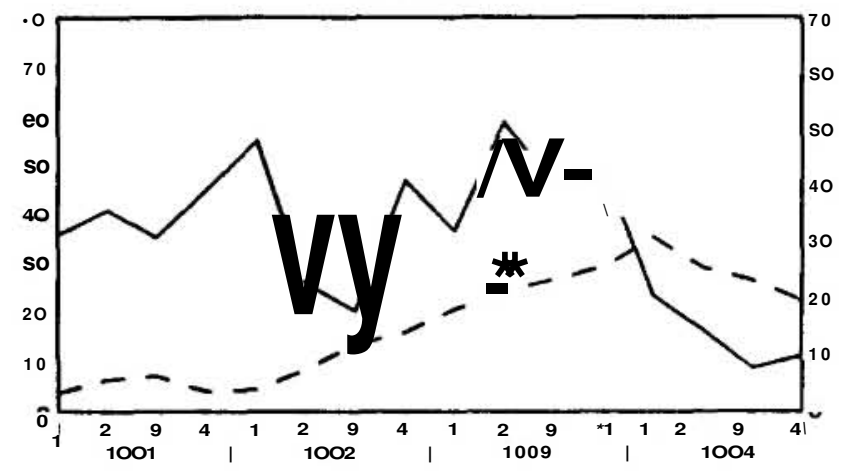

Latvia

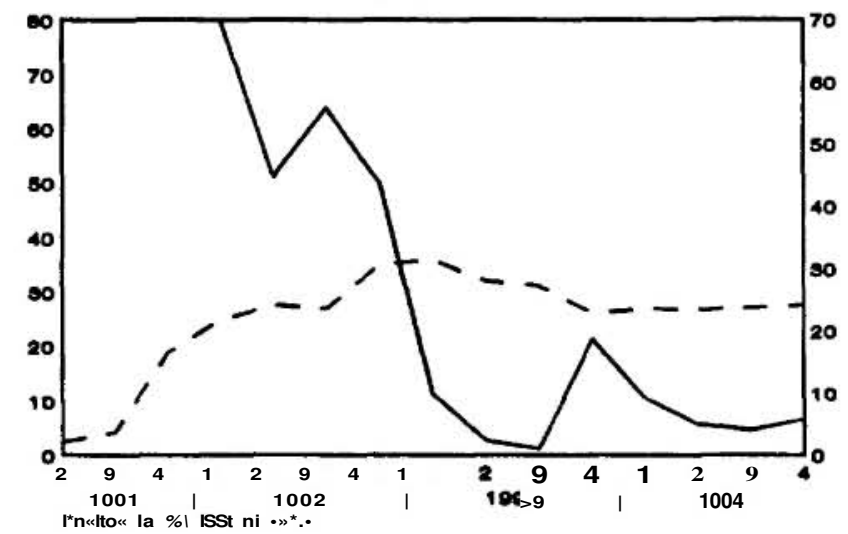

Ukraine 2/

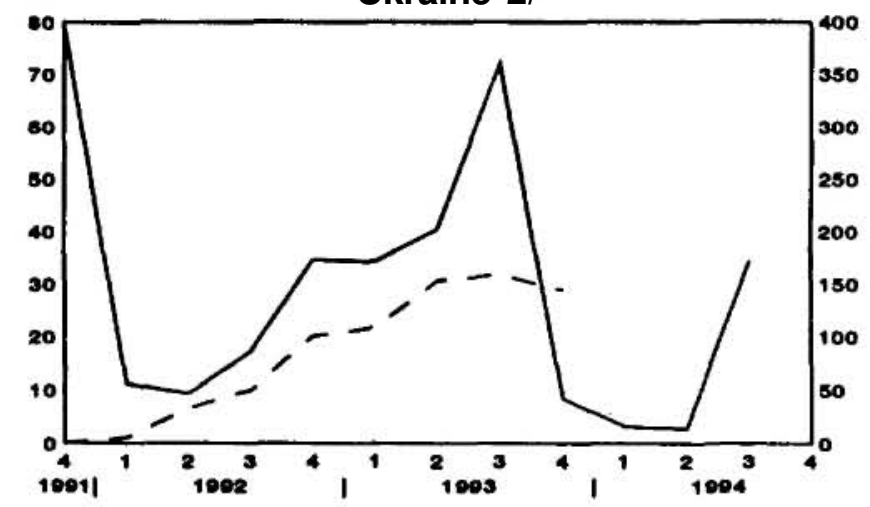

Mongolia

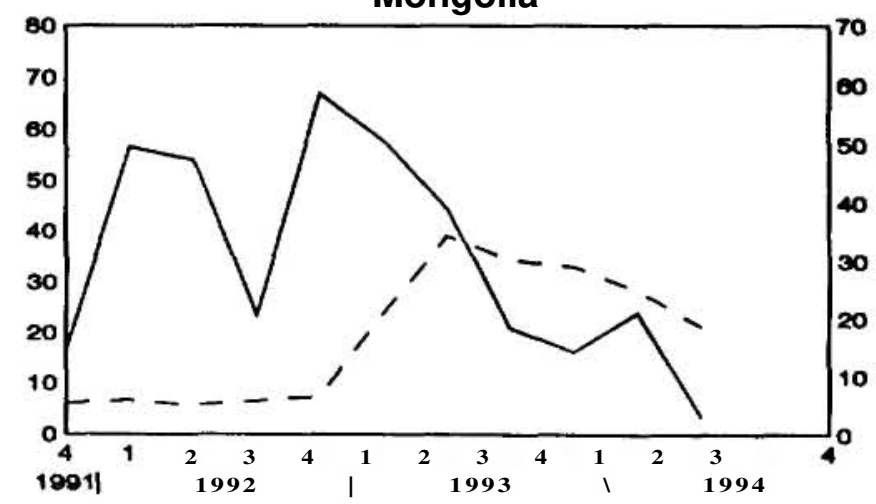

1/ DolUriation la measured by the ratio of foreign currency deposit* to broad money (including foreign currency deposits).

Kote Ihtt the inflation icilei differ for Bulfirii, Runia uI ITkraine.

$£ /$ Foreign currency Aepoilti ev«Wtied tl »MCUOS eichtnfe rile. 
was financed for the most part by monetary expansion. Thus, with the break up of the former Soviet Union, Russia and Ukraine inherited economies with large macroeconomic imbalances and disintegrating economic institutions.

Economic performance in Russia and Ukraine in 1992 deteriorated further: output continued to decline, large budget deficits were monetized, and little progress was made on structural reforms. Dollarization quickly took momentous significance as financial reforms allowing foreign currency deposits coincided with the onset of high inflation, depreciating exchange rates, and rapidly declining real domestic interest rates.

In Russia, the dollarization ratio rose from a little over 15 percent in December 1991 to nearly 45 percent in mid-1993, and has fluctuated in the 35-40 percent range ever since (Figure 2). 1/ Commercial bank credit in foreign currency has also grown very rapidly. Total bank credit to the nongovernment sector increased nearly 20-fold between end-1992 and mid-1994, with the ratio of ruble-denominated to foreign currency-denominated credit declining from over 7.5 to about 3 during the same period. Since there are no reserve requirements on foreign currency deposits (as of mid-1994), the scope for broad money growth (and therefore higher inflation) is potentially very high.

In Ukraine, dollarization emerged for the first time in March 1992 and increased to nearly 20 percent in June 1993 (Figure 2). Between December 1992 and March 1993, the dollarization ratio in Ukraine shot up rapidly by nearly 10 percentage points with the relaxation of exchange controls on surrender requirements. Following a brief period of unified and marketdetermined exchange rates, however, a multiple rate regime was introduced in August 1993, with further tightening of surrender requirements at a highly appreciated exchange rate. The new system encouraged capital flight and barter trade and drove traders to the informal economy. Another factor that has contributed to keeping the dollarization ratio low in Ukraine is the fact that, despite high inflation, the demand for cash during 1993 has increased sharply relative to (domestic- and foreign-currency) deposits, probably reflecting the growth of informal markets and decreased confidence in the domestic banking system. $2 J$

5. Stabilization with de-dollarization: the Baltic Republics and Mongolia

The reform process in Estonia began in late 1989 with price liberalization and accelerated in 1990-91 with the adoption of fiscal and banking reforms. Latvia and Lithuania were late starters relative to Estonia, embarking on a comprehensive reform program only in mid-1992. During 1992,

1/ Since the quality of the Russian data is uncertain, these figures should be viewed only as suggestive.

2/ The ratio of currency to total deposits increased from less than 20 percent in March 1993 to over 50 percent in March 1994. 
all three economies were jolted by the economic upheaval provoked by the collapse of the former Soviet Union, and faced sizable trade disruptions and terms of trade shocks as Russia raised the price of oil and other primary exports to world market levels. Ruble cash shortages and interruptions in the inter-republican payments mechanism compounded the external shock.

As part of their stabilization programs, all three countries adopted tight financial policies supported by incomes policy measures. Perhaps the most striking measure that expedited the stabilization effort in all three countries was a currency reform. 1/ Estonia introduced a currency board and replaced the ruble with the kroon in mid-1992; Latvia introduced the Latvian ruble as a transitional currency also in mid-1992; and Lithuania circulated provisional coupons, the talonas, alongside the rubles in october 1992. Latvia and Lithuania then replaced their transitional currencies in March and June 1993, respectively. Lithuania finally introduced a currency board in April 1994. The annual average inflation rate fell from over 1,000 percent in Estonia and about 950 percent in Latvia in 1992 to 89 percent and 109 percent in 1993, respectively. The monthly inflation rates declined to 5 percent by year-end in both countries. Despite tight policies, Lithuania was less successful in reducing inflation, which averaged about 410 percent in 1993 compared to 1,020 percent in 1992 .

Among the 15 transition economies in the sample, Latvia has the most liberal laws regarding the public's holdings of foreign currency. Residents can hold foreign currency in the form of cash, in bank accounts at home and abroad, and are allowed to use foreign currency for making domestic payments. Of the three Baltic Republics, Estonia's foreign exchange regulations are the least liberal. After the currency reform in Estonia, foreign currency accounts of resident households and enterprises in domestic banks could be maintained but not augmented.

Dollarization took place at a fairly rapid pace in the Baltic Republics (Figures 1 and 2 ). In the face of sharply accelerating prices, negative real domestic interest rates, and large devaluations in the early stages of reform, foreign currency deposits proved to be a better alternative as a saving instrument than domestic currency deposits. The dollarization ratio peaked at around 60 percent in Estonia in the second quarter of 1992, 50 percent in Lithuania in the first quarter of 1993, and 35 percent in Latvia in the first quarter of 1993. Since then, with a sharp decline in inflation, the ratio declined very rapidly in Estonia and Lithuania. In addition to the tighter regulations on foreign currency deposits in Estonia, the declining trend indicates the success and credibility of the stabilization program based on a currency board. In Latvia, on the other hand, the dollarization ratio has declined only slightly, which may be partly explained by the fact that, given its liberal foreign exchange markets,

1/ These countries were among the first to introduce their own currency after the dissolution of the former Soviet Union. On Estonia, see Benett (1993). 
Latvia has provided a "safe haven" for residents of other high inflation countries of the former Soviet Union (like Russia and Ukraine).

The pattern of dollarization in Mongolia has been similar to that of the Baltic Republics and Poland, which have pursued successful stabilization programs (Figure 2). With the liberalization of the exchange and trade system in 1990, and the sharp increase in inflation rates at the outset of the transition in 1991-92, the dollarization ratio rose from 2 percent at end-1989 to almost 40 percent in mid-1993. The fall in inflation and the rise in real returns on domestic currency deposits during 1993 caused a de-dollarization in Mongolia, albeit with a lag (see Morsink, 1994).

\section{Policy Implications}

This section discusses some key conceptual and policy questions related to dollarization in light of the evidence presented in the previous section. In particular, this section examines the role of institutional factors, the importance of real rates of return for portfolio diversification, the problems in conducting monetary policy in a highly dollarized economy, and whether dollarization should be actively discouraged or not.

\section{The importance of institutional factors}

While the demand for foreign currency (and, more generally, foreigncurrency denominated assets) is mainly determined by macroeconomic factors, the availability of foreign currency depends crucially on local institutional constraints. The absence of any dollarization during the pre-reform period in most transition economies was primarily due to the tight controls on foreign exchange and the banking system. With the advent of large-scale market oriented reforms, two institutional factors were critical in bringing about rapid dollarization. First, at the very start of the reform programs, foreign exchange regimes were substantially liberalized. Second, due to the inherent difficulties in bringing about swift reforms in the financial sector, alternative savings instruments (like domestic-currency assets bearing market interest rates) were simply not available. Thus, in the face of high inflation, the liberalization of foreign exchange rate regimes laid the grounds for rapid dollarization, which was sustained by the lack of alternative financial instruments.

The institutional constraints on foreign currency deposits in the transition economies also appear to be related to the exchange rate regime. Countries with fixed exchange rate regimes generally have full repatriation and full surrender requirements of exports proceeds, as well as restrictions on capital account convertibility. Such constraints may have contributed to low dollarization ratios in some countries (like in Hungary) or to the rapid decline in the dollarization ratio in others (Poland imposed such controls in 1990 and Estonia in June 1992). Presumably, the fact that countries with relatively fixed exchange rate regimes have had tighter foreign exchange controls reflects the authorities' desire to defend the fixed regime with 
adequate levels of external reserves. In contrast, transition economies with more flexible exchange rate regimes have had fewer restrictions.

To a large extent, similar institutional considerations were present early on in some of the highly dollarized countries of Latin America-Bolivia, Mexico, Peru, and Uruguay. In all four countries, the decision to allow foreign currency deposits in the early 1970s was either preceded or accompanied by large devaluations and by the adoption of more flexible exchange rate regimes. These measures were aimed in part at protecting the stock of official reserves from the private sector's portfolio recomposition that could result from the lifting of foreign exchange controls. Unlike in the transition economies, however, restrictions on capital account convertibility were rare until the early 1980s when foreign exchange controls--which included the forced conversion of existing foreign currency deposits into domestic currency deposits--were reimposed in Bolivia, Mexico, and Peru. Eventually, foreign currency deposits were allowed once again in all three countries.

Finally, an interesting feature observed in transition economies-especially in the former Soviet Union--is that the currency to deposit ratio has generally risen during the first couple of years of reform. This probably reflects a lack of public confidence in the banking system (including the fear of confiscation of deposits), low deposit rates on domestic money, and the relative underdevelopment of the financial markets. The rapid growth of the small-scale private sector and the black (untaxed) economy may have contributed further to this phenomenon. The rise in both the dollarization ratio and the currency to deposit ratio in these countries clearly points to the increasing undesirability of holding domestic currency deposits. An improvement in the fiscal and financial system and the introduction of market-related instruments can be expected to lead to a rise in both domestic and foreign currency deposits relative to cash.

\section{Dollarization and real rates of return}

The experience of several Latin American countries would suggest the existence of "hysteresis" in the dollarization ratio (see, for instance, Dornbusch and Reynoso (1989), Guidotti and Rodriguez (1992), Kamin and Ericsson (1993), and Clements and Schwartz (1993)). 1/ "Hysteresis" refers to the fact that dollarization ratios have remained high even in the face of declining inflation rates. Such phenomenon cannot be explained by traditional currency substitution models which, following Calvo and Rodriguez (1977), assume that (non-interest bearing) foreign assets compete with domestic money in providing liquidity services. These models capture currency substitution with an equation such as (7) in the model described

1/ The notion of hysteresis--also known as the "ratchet" effect--has a long history in the money-demand literature, as discussed by Mueller (1994) and Kamin and Ericsson (1993). 
in Section II: the ratio of foreign- to domestic-currency denominated assets depends positively on the nominal interest rate. Therefore, a fall in inflation (i.e., a fall in domestic nominal interest rates) should lower the demand for foreign currency relative to domestic currency.

To explain hysteresis in these models, it is necessary to assume that there are some costs associated with the process of currency substitution which make it irreversible. 1/ Dornbusch and Reynoso (1989) and Dornbusch, Sturzenegger, and Wolf (1990) argue that processes of financial adaptation are costly (due to sunk costs and learning by doing), which make them irreversible. In a related explanation, Guidotti and Rodriguez (1992) assume that it is costly to switch between currencies and show that there is a "band" for the inflation differential above which dollarization continues to occur even if inflation falls. A similar result is derived by Sturzenegger (1993), who emphasizes the "public good" aspect of currency substitution by assuming that it is costly to transact in foreign currency but only to the extent that others have not yet begun to use it. Uribe's (1994) model also emphasizes the relation between the private cost of transacting and the aggregate degree of dollarization.

Although the theoretical literature has been built around the notion of currency substitution, in practice one can only hope to measure the extent of dollarization (and only imperfectly, as noted in Section III), by using data on interest-bearing foreign-currency denominated time deposits. As the model of Section II makes clear, however, the dollarization ratio should respond only to differences in real rates of return between domestic- and foreign-currency denominated assets. A fall in the domestic inflation rate would have no effect whatsoever on dollarization, except to the extent that it may affect real rates of return. Hence, de-dollarization would result only from a higher real return on domestic-currency denominated assets. Conversely, dollarization would be the consequence of very low (and even negative) real rates of return on domestic-currency denominated assets, combined with the institutional freedom to invest in foreign-currency denominated assets at home. $\frac{J}{J}$ In fact, according to Dornbusch and Reynoso (1989), declining real rates of return on domestic-currency

1/ Incidentally, note that the whole debate over hysteresis is in itself a good example of the conceptual pitfalls that might be involved when no distinction is drawn between currency substitution and dollarization. In effect, data on dollarization (equation (7)) has been used to argue that equation (4) does not work. This is conceptually not valid unless one can convincingly argue that all foreign-currency time deposits were extremely liquid and should be thought of as "f" rather than "b" in the model.

$2 /$ It seems interesting to note that most practitioners--and probably with good reason--seem to have a portfolio model of dollarization in their mind, as evidenced by the fact that in policy discussions it is commonly argued that a rise in (real) interest rates on domestic-currency denominated assets should lead to a de-dollarization of the economy. Such logic would not hold in a Calvo-Rodriguez type model of currency substitution. 
denominated assets over prolonged periods of time are capable of explaining dollarization in several Latin American countries.

While high inflation is a typical characteristic of periods during which real returns on domestic-currency denominated assets decline substantially (or even turn negative), a critical ingredient is that, due to financial repression or related considerations, nominal returns do not adjust accordingly. Long periods of chronic inflation are entirely consistent with a very low degree of dollarization if, as has been the case in Brazil and Chile, the financial system adapts and offers indexed domestic-currency denominated assets, which keeps real rates of return relatively attractive. Therefore, portfolio considerations, which have been largely ignored in the literature, are arguably key in understanding dollarization. 1/

The above considerations should be useful in interpreting the experiences of transition economies where, unlike what has happened in Latin American countries, dollarization seems to have fallen in response to a reduction in inflation rates, most notably in Estonia, Lithuania, Mongolia, and Poland. This would be consistent with the traditional currency substitution hypothesis (captured by equation (7)), combined with the absence of hysteresis which is likely to arise only after prolonged periods of dollarization. This interpretation, however, would rest on the assumption that foreign currency deposits were held primarily as a means of exchange and were not receiving market interest rates (in which case, they would be roughly equivalent to "f" in the theoretical model of Section II). g/

Alternatively, if one takes the view that interest-bearing foreign currency deposits are held mainly as a store of value (clearly, the most reasonably assumption), then it could be argued that higher real returns on domestic-currency denominated assets relative to foreign-currency denominated assets have contributed to making domestic-currency assets more attractive in the transition economies. This point can be illustrated by a cross-country comparison of the dollarization process and the real returns on the domestic-currency denominated assets observed during 1992-93.

1/ It does not follow, however, that high interest rates on domesticcurrency denominated assets are necessarily a good policy (see the discussion below).

2/ It should be noted that it is believed that foreign currency holdings are large in some transition economies, especially in Russia. 
Tables 1 through 4 report real deposits rates on domestic-currency deposits and--where available--the deposit rate spread between domestic- and foreign-currency deposits for Estonia, Lithuania, Mongolia, and Poland. 1/ The general pattern is one of highly negative real rate of deposits and negative spreads early on, with both turning positive later. Mongolia is perhaps the most striking case (Table 3): after being highly negative until mid-1993, real deposits rates and deposit rate spreads became positive at which point--as portfolio considerations would predict--the dollarization process reversed sharply (Figure 2). A similar story applies to Lithuania, where the fall in the dollarization ratio that began in early 1993

(Figure 1) coincides with a switch from highly negative real deposit rates to generally positive returns (Table 2). In Poland (Table 4), substantial variations tend to obscure the underlying trend, but it can be seen that the highly negative real returns during 1987-1990 were followed by much higher, albeit often still negative, returns. Finally, the sparse data available for Estonia (Table 1) indicate that, while ex-post real deposits rates have been negative, the devaluation-adjusted deposits rates have been substantially higher than international rates. While higher real interest rates on domestic-currency assets in all four countries may be partly due to tight monetary policies associated with stabilization plans, in general they reflect more fundamental and permanent forces such as further progress in financial liberalization and, in particular, a greater role of market forces in the determination of nominal interest rates. $2 /$ In contrast, in those countries in which dollarization ratios have remained high--such as Albania, Bulgaria, and Russia--real deposits rates have been negative and often declining. $1 /$

To the extent that the phenomenon of dollarization captures portfolio considerations, it is intimately related to capital flows. More specifically, the choice between foreign currency deposits at home (dollarization) and foreign currency deposits abroad (capital flight) will be influenced by institutional, regulatory, and credibility considerations (like fear of confiscation). In this light, one would expect a period of dollarization to coincide with surges in capital inflows (partly reflecting the return of flight capital). Indeed, the evidence provided in Calvo, Sahay, and végh (1995) shows that, beginning in 1992, there has been a sharp reversal in capital flows to Central and Eastern Europe. During 1993,

1/ The deposit rate spread was computed by comparing nominal interest rates on domestic deposits (adjusted by the devaluation rate) with interest rates on foreign-currency deposits. Naturally, if this spread is, say, positive, so is the spread in real terms, which is what should matter for portfolio decisions. The usual caveats regarding the fact that these are ex-post, rather than ex-ante, returns apply.

2/ In the particular case of Mongolia, the rise on real return on domestic currency deposits was also related to the enactment of minimum deposit rate legislation (Morsink, 1994).

3/ The data, not reported, are available from the authors upon request. 
Table 1. Estonia-Deposit Rates, 1991-94 l J

(period end, in percent per annum)

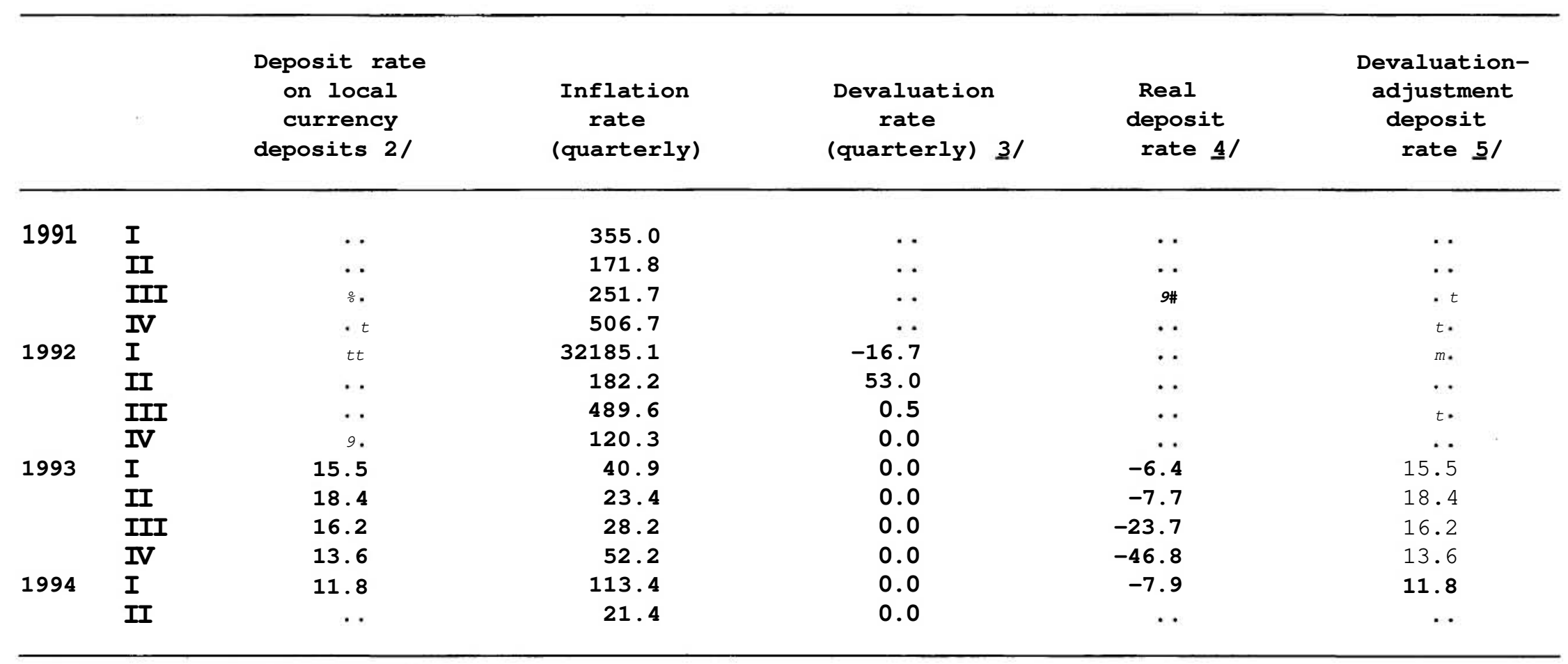

Source: National authorities.

1/ Deposit rates on foreign currency deposits are not available.

2/ Average time deposit rate over all maturities; no breakdown available.

3/ The devaluation rate is calculated with respect to the deutsche mark.

4/ Based on one-period ahead quarterly (annualized) inflation.

5/ Based on one-period ahead quarterly (annualized) devaluation rate. 
Table 2. Lithuania--Deposit Rates, 1991-94 1/ (period end, in percent per annum)

\begin{tabular}{|c|c|c|c|c|c|c|c|c|}
\hline & & $\begin{array}{c}\text { Deposit } \\
\text { rate } \\
\text { on foreign } \\
\text { currency } \\
\text { deposits }\end{array}$ & $\begin{array}{l}\text { Deposit } \\
\text { rate } \\
\text { on local } \\
\text { currency } \\
\text { deposits }\end{array}$ & $\begin{array}{c}\text { Inflation } \\
\text { rate } \\
\text { (quarterly) }\end{array}$ & $\begin{array}{c}\text { Devaluation } \\
\text { rate } \\
\text { (quarterly) }\end{array}$ & $\begin{array}{c}\text { Real } \\
\text { deposit } \\
\text { rate } 2 /\end{array}$ & $\begin{array}{c}\text { Devaluation- } \\
\text { adjusted } \\
\text { deposit } \\
\text { rate } 3 /\end{array}$ & $\begin{array}{l}\text { Deposit } \\
\text { rate } \\
\text { spread } \underline{4} /\end{array}$ \\
\hline \multirow[t]{4}{*}{1991} & $I$ & . & 2.0 & . & . & -79.0 & . & . \\
\hline & II & . & 2.0 & 386.2 & $\ldots$ & -39.1 & . & $\ldots$ \\
\hline & III & $\ldots$ & 2.0 & 67.6 & . & -94.5 & -98.2 & $\ldots$ \\
\hline & IV & $\ldots$ & 2.0 & 1745.5 & $5619^{\wedge} 1$ & -97.7 & 2.0 & . \\
\hline \multirow[t]{4}{*}{1992} & $I$ & $\ldots$ & 22.0 & 4414.3 & 0.0 & -60.2 & -39.3 & $\ldots$ \\
\hline & II & \#. & . & 206.3 & 101.1 & $\ldots$ & $\mathrm{mm}$ & . \\
\hline & III & .. & 62.0 & 1150.0 & 1143.5 & -89.0 & -72.1 & $\ldots$ \\
\hline & IV & 26.0 & 98.0 & 1371.8 & 481.5 & -57.0 & -52.6 & -62.3 \\
\hline \multirow[t]{4}{*}{1993} & $I$ & 22.0 & 96.0 & 360.0 & 317.4 & -61.0 & 386.4 & 298.8 \\
\hline & II & 25.0 & 105.0 & 402.9 & -59.7 & 49.6 & 346.9 & 257.5 \\
\hline & III & 26.0 & 92.0 & 37.0 & -54.1 & -12.5 & 29.6 & 2.8 \\
\hline & IV & 33.0 & 83.0 & 119.4 & 48.2 & 21.6 & 74.0 & 30.8 \\
\hline \multirow[t]{2}{*}{1994} & $I$ & .. & 65.0 & 50.5 & 5.2 & 9.4 & 65.0 & $\ldots$ \\
\hline & II & .. & . & 50.8 & 0.0 & . & . & . \\
\hline
\end{tabular}

Source: National authorities.

J// Note: Data prior to 1992 Q4 are rough estimates and may not be comparable with later data.

2/ Based on one-period ahead quarterly (annualized) inflation.

3/ Based on one-period ahead quarterly (annualized) devaluation rate.

$\underline{4}$ / The difference between deposit rates on domestic currency and foreign currency (adjusted for the devaluation rate). 
Table 3. Mongolia-Deposit Rates, 1991-94

(period end, in percent per annum)

\begin{tabular}{|c|c|c|c|c|c|c|c|c|c|c|c|}
\hline & \multirow{2}{*}{$\frac{1991}{\text { QIV }}$} & \multicolumn{4}{|c|}{1992} & \multicolumn{4}{|c|}{1993} & \multicolumn{2}{|c|}{1994} \\
\hline & & QI & QII & QIII & QIV & QI & QII & QIII & $\overline{Q I V}$ & QI & QII \\
\hline & & & & & & & . & & & & \\
\hline Domestic currency (1-3 years) & 6.0 & 6.0 & 6.0 & 28.0 & $50-70$ & $54-84$ & $60-152$ & $90-152$ & $70-153$ & $70-153$ & $50-130$ \\
\hline Foreign Currency (1-3 years) & 8.0 & 8.0 & 8.0 & 10.0 & 40.0 & $48-60$ & $48-70$ & $15-70$ & $10-72$ & $10-72$ & $10-84$ \\
\hline Quarterly inflation rate & 71.2 & 400.6 & 371.5 & 110.6 & 532.8 & 415.2 & 271.9 & 96.7 & 69.9 & 114.8 & 12.5 \\
\hline Quarterly devaluation rate & 0.0 & 0.0 & 0.0 & 0.0 & 0.0 & 19675.0 & 4956.8 & -10.6 & 7.4 & 19.8 & -1.1 \\
\hline Real deposit rate (low) $1 /$ & -78.8 & -77.5 & -49.7 & -79.8 & -70.9 & -58.6 & -18.7 & 11.9 & -20.9 & 51.1 & . \\
\hline Real deposit rate $($ high) $\underline{1} /$ & -78.8 & -77.5 & -49.7 & -79.8 & -67.0 & -50.5 & 28.1 & 48.4 & 17.8 & 124.8 & . \\
\hline Deval-adjusted deposit rate (low) 2 / & 6.0 & 6.0 & 6.0 & 28.0 & -99.2 & -97.0 & 78.9 & 76.9 & 41.9 & 72.0 & . \\
\hline Deval-adjusted deposit rate (high) $\underline{2}$ / & 6.0 & 6.0 & 6.0 & 28.0 & -99.1 & -96.4 & 181.7 & 134.6 & 111.2 & 155,9 & $\bullet$ \\
\hline Deposit rate spread (low) $3 /$ & -1.9 & -1.9 & -1.9 & 16.4 & -99.5 & -97.9 & 20.9 & 53.8 & 29.0 & 56.3 & . \\
\hline Deposit rate spread (high) $3 /$ & -1.9 & -1.9 & -1.9 & 16.4 & -99.5 & -97.7 & 65.7 & 34.1 & 22.8 & 48.6 & .. \\
\hline
\end{tabular}

Source: Bank of Mongolia; National authorities.

$1 /$ On domestic currency. Based on quarterly inflation (annualized) one-period ahead. "Low" and "high" refer to the ranges of the nominal deposit rate.

2/ On domestic currency. Based on quarterly devaluation rate (annualized) one-period ahead. "Low" and "high" refer to the ranges of the nominal deposit rate.

3/ The difference between deposit rates on domestic currency and foreign currency (adjusted for the devaluation rate). The spread for the "low" ("high") is the difference between the low (high) deposit rates on domestic and foreign currency. 
Table 4. Poland: Deposit Rates, 1987-94

(period end, in percent per annum)

\begin{tabular}{|c|c|c|c|c|c|c|c|c|c|c|c|c|c|}
\hline & & \multicolumn{2}{|c|}{$\begin{array}{c}\text { zloty } \\
\text { deposits } 1 /\end{array}$} & \multicolumn{2}{|c|}{$\begin{array}{c}\text { US } \$ \\
\text { deposits } 2 /\end{array}$} & \multirow{2}{*}{$\begin{array}{l}\text { Inflation } \\
\text { rate } g f\end{array}$} & \multirow{2}{*}{$\begin{array}{l}\text { Devalu- } \\
\text { ation } \\
\text { rate } \underline{3}\end{array}$} & \multicolumn{2}{|c|}{$\begin{array}{l}\text { Real } \\
\text { Deposit } \\
\text { rate } 4 / \\
\end{array}$} & \multicolumn{2}{|c|}{$\begin{array}{l}\text { Devaluation- } \\
\text { adjusted } \\
\text { deposit rate 5/ }\end{array}$} & \multicolumn{2}{|c|}{$\begin{array}{l}\text { Deposit } \\
\text { rate } \\
\text { spread } \\
\end{array}$} \\
\hline & & Low & High & Low & High & & & Low & High & Low & High & Low & High \\
\hline 1987 & & 5.0 & . & 5.0 & 5.0 & 26.4 & 51.4 & -16.9 & . & -30.7 & . & -34.0 & .. \\
\hline 1988 & & 10.0 & .. & 5.0 & 5.0 & 58.7 & 62.6 & -30.7 & . & -32.4 & . & -35.6 & .. \\
\hline 1989 & & 33.0 & 120.0 & 5.0 & 5.0 & 244.6 & 233.9 & -61.4 & -36.1 & -60.2 & -34.1 & -62.1 & -37.2 \\
\hline 1990 & & 54.0 & 59.0 & 5.0 & 5.0 & 555.4 & 560.2 & -76.5 & -75.7 & -76.7 & -75.9 & -77.8 & -77.1 \\
\hline 1991 & $\begin{array}{l}\text { I } \\
\text { II } \\
\text { III } \\
\text { IV }\end{array}$ & $\begin{array}{l}70.0 \\
54.0 \\
38.0 \\
36.0\end{array}$ & $\begin{array}{l}78.0 \\
66.0 \\
48.0 \\
46.0\end{array}$ & $\begin{array}{r}\ldots \\
5.0 \\
5.0 \\
5.0\end{array}$ & $\begin{array}{r}. .0 \\
8.0 \\
8.0 \\
8.0\end{array}$ & $\begin{array}{r}150.3 \\
49.0 \\
21.8 \\
45.5\end{array}$ & $\begin{array}{r}0.0 \\
111.6 \\
-12.1 \\
-4.9\end{array}$ & $\begin{array}{r}14.1 \\
26.5 \\
-5.2 \\
-12.6\end{array}$ & $\begin{array}{r}19.4 \\
36.3 \\
1.7 \\
-6.1\end{array}$ & $\begin{array}{r}-19.7 \\
75.1 \\
45.1 \\
-40.9\end{array}$ & $\begin{array}{r}-15.9 \\
88.7 \\
55.7 \\
-36.6\end{array}$ & $\begin{array}{r}\ddot{66.8} \\
38.2 \\
-43.7\end{array}$ & $\begin{array}{r}74.8 \\
44.1 \\
-41.3\end{array}$ \\
\hline 1992 & $\begin{array}{l}\text { I } \\
\text { II } \\
\text { III } \\
\text { IV }\end{array}$ & $\begin{array}{l}36.0 \\
36.0 \\
32.0 \\
32.0\end{array}$ & $\begin{array}{l}49.0 \\
49.0 \\
43.3 \\
42.0\end{array}$ & $\begin{array}{l}4.5 \\
4.5 \\
4.5 \\
4.5\end{array}$ & $\begin{array}{l}9.0 \\
9.0 \\
9.5 \\
7.0\end{array}$ & $\begin{array}{l}55.5 \\
43.9 \\
44.4 \\
34.4\end{array}$ & $\begin{array}{r}130.2 \\
0.4 \\
12.3 \\
65.1\end{array}$ & $\begin{array}{l}-5.5 \\
-5.8 \\
-1.8 \\
-9.4\end{array}$ & $\begin{array}{r}3.5 \\
3.2 \\
6.6 \\
-2.5\end{array}$ & $\begin{array}{r}35.4 \\
21.1 \\
-20.1 \\
6.8\end{array}$ & $\begin{array}{r}48.3 \\
32.7 \\
-13.2 \\
14.9\end{array}$ & $\begin{array}{r}29.6 \\
15.9 \\
-23.5 \\
2.2\end{array}$ & $\begin{array}{r}36.1 \\
21.7 \\
-20.7 \\
7.3\end{array}$ \\
\hline 1993 & $\begin{array}{l}\text { I } \\
\text { II } \\
\text { III } \\
\text { IV }\end{array}$ & $\begin{array}{l}25.0 \\
25.0 \\
25.0 \\
25.0\end{array}$ & $\begin{array}{l}36.0 \\
36.0 \\
36.0 \\
34.0\end{array}$ & $\begin{array}{l}3.0 \\
3.0 \\
2.5 \\
2.8\end{array}$ & $\begin{array}{l}5.5 \\
5.5 \\
4.5 \\
5.0\end{array}$ & $\begin{array}{l}45.7 \\
24.4 \\
26.3 \\
57.0\end{array}$ & $\begin{array}{l}23.6 \\
30.7 \\
51.9 \\
36.8\end{array}$ & $\begin{array}{r}0.5 \\
-1.1 \\
-20.4 \\
2.9\end{array}$ & $\begin{array}{r}9.3 \\
7.7 \\
-13.4 \\
10.3\end{array}$ & $\begin{array}{r}-4.4 \\
-17.7 \\
-8.6 \\
8.4\end{array}$ & $\begin{array}{r}4.1 \\
-10.5 \\
-0.6 \\
16.2\end{array}$ & $\begin{array}{r}-7.1 \\
-20.1 \\
-10.9 \\
5.5\end{array}$ & $\begin{array}{r}-1.4 \\
-15.1 \\
-4.9 \\
10.7\end{array}$ \\
\hline 1994 & I & 25.0 & 34.0 & 2.8 & 5.0 & 21.5 & 15.3 & .. & . & . & .. & . & . \\
\hline
\end{tabular}

Sources: National Bank of Poland; IFS.

1/ Interest rates on 6 -month deposits.

2/ Annual average inflation for 1986-90; end-period quarterly inflation (annualized) during 1991-94.

3/ Annual average devaluation rate for 1986-90; end-period quarterly devaluation rate (annualized) during $1991-1994$.

kf Based on contemporaneous annual average inflation for 1986-90; end-period quarterly inflation one period ahead for 1991-94.

5/ Based on contemporaneous annual average devaluation rate for 1986-90; end-period quarterly devaluation rate one period ahead for 1991-94.

6/ The difference between deposit rates on domestic currency and foreign currency (adjusted for the devaluation rate). The spread for the "Low"

("High") is the difference between the Low (High) deposit rates on domestic and foreign currency. 
capital inflows amounted to around US\$ 12 billion, roughly 6 percent of GDP for the region as a whole.

\section{Monetary policy in a highly dollarized economy}

It is often argued that a high degree of dollarization hinders the ability of policymakers to conduct monetary policy effectively. The basic idea is that the relevant monetary aggregate (i.e., the one which determines the domestic price level and influences economic activity) may be the one that includes foreign currency deposits expressed in domestic currency terms. I $J$ since the latter cannot be controlled by the monetary authorities, the relevant money supply may become endogenous and the economy may lose its nominal anchor. 1/ In the extreme case in which domestic and foreign money are perfect substitutes, the economy is left with no nominal anchor and the exchange rate is indeterminate (Kareken and Wallace, 1981). From a policy perspective, the endogeneity of the money supply implies that the authorities may be unable to reduce inflation by tightening the domestic component of the money supply. 3/ This loss of monetary control might be particularly relevant in transition economies where the removal of institutional constraints on foreign currency holdings may lead to sudden portfolio shifts.

Ultimately, the practical importance of this issue is an empirical question insofar as the relevant monetary aggregate may vary from country to country and, even within a country, over time. $4 /$ In the case of Uruguay--a highly dollarized economy--recent econometric evidence suggests that dollarization may severely hinder the effectiveness of monetary policy (see Hoffmaister and Végh, 1994). 5/ Policy simulations indicate that a disinflationary policy based on reducing the rate of growth of M1 or M2 (which exclude foreign currency deposits) leads to a much slower fall in inflation, compared to using the exchange rate as the nominal anchor.

$1 /$ Note that this argument presupposes that either (i) foreign currency deposits are highly liquid, or (ii) they affect nominal expenditure through a wealth effect. Otherwise, there would be no reason, at least in theory, for a broad monetary aggregate to affect the price level.

2/ Naturally, this argument applies under floating exchange rates. Under fixed (or predetermined) exchange rates, the money supply would be endogenous even in the absence of foreign currency deposits.

ZJ Naturally, this does not mean that inflation is being "caused" by dollarization and the resulting ineffectiveness of monetary policy. Quite to the contrary, dollarization is typically the result of high inflation combined with negative real returns.

4/ Theory offers so far little guidance regarding what monetary aggregate (i.e., the monetary base, M1, M2, or even broader aggregates) should be the more relevant in determining nominal GDP and thus inflation. See Friedman (1990).

5/ The dollarization ratio in Uruguay (excluding deposits of nonresidents) is around 70 percent. 
The loss of effectiveness of monetary policy in a highly dollarized economy makes, other things being equal, an exchange rate anchor more desirable. Naturally, there are many other important macroeconomic and institutional considerations involved in choosing a nominal anchor in transition economies, ranging from the availability of international reserves and instruments of indirect monetary control to the credibility of a given policy stance (see Sahay and Végh, 1995). In principle, the weight to be given to the dollarization factor in the choice of a nominal anchor should be dictated by (i) the extent of dollarization, (ii) the degree of openness of the economy, and (iii) the extent to which broader monetary aggregates (that include foreign currency deposits) are the relevant determinants of inflation and economic activity. clearly, targeting a monetary aggregate in a small, very open, and highly dollarized economy would not be advisable.

\section{Should dollarization be resisted?}

While allowing foreign currency deposits may have important benefits for an economy (such as reversing capital flight, building international reserves, and providing a more efficient allocation of financial resources), some negative consequences are inevitable (see Calvo and végh, 1992). First, to the extent that dollarization gets reflected in a shift away from domestic money, it will exacerbate the inflationary consequences of a given fiscal deficit. Hence, as the experience of Latin America suggests, fiscal discipline is all the more important in highly dollarized economies. Second, as discussed above, the authorities' ability to conduct monetary policy may be substantially undermined because the foreign currency component of the total (broad) money supply cannot be directly controlled. This factor may have contributed to sustaining inflation in countries such as Bulgaria, Romania, Russia, and Ukraine.

In spite of these potential problems, the experience of Latin America suggests that combating dollarization with artificial measures--such as using indexed financial instruments, paying interest on highly liquid assets which are used as money, or forcing the conversion of foreign assets into domestic assets--merely contributes to magnifying the eventual inflationary explosion. Dollarization is often one of the manifestations--and certainly not the cause--of underlying fiscal and monetary disequilibria which are reflected in chronic fiscal deficits and accommodative monetary and exchange rate policy. Attacking the symptoms of the disease rather than its root causes may very well worse the situation.

Over the last two decades, Brazil has offered an instructive example of a "successful" fight against dollarization without, however, addressing the fundamental problems. In particular, the case of Brazil is a prime example of the fact that, even in the face of very high and variable inflation, ensuring an attractive real rate of return on domestic-currency denominated assets can certainly succeed in preventing dollarization. High (and often 
increasing) interest rates can entice the public to roll over its domestic currency deposits rather than switch to foreign currency deposits. 1/

In conjunction with chronic fiscal deficits, however, such an interest rate policy may lead to a situation in which commercial banks hold almost of all their assets in the form of interest-bearing government paper of very short maturities, which they issue to the public as interest-bearing money. 2/ As a result, not only is inflation out of control due to the lack of a nominal anchor--as the relevant money supply becomes largely endogenous and the exchange rate accommodates inflation--but there also exists a permanent risk of a funding crisis if the government is not able to roll over its debt on virtually a daily basis. In sum, the ultimate price of "winning the battle" against dollarization can certainly be exorbitant, while at the same time the underlying fundamental problems are left untouched.

Naturally, a move towards a greater use of domestic-currency denominated assets would be welcome if it reflects sound financial and fiscal policies. By the same token, some dollarization of the economy as a result of financial liberalization should be viewed as a natural outcome of portfolio diversification in a world of high capital mobility. An important lesson from the experience of Latin American countries for economies in transition is that allowing FCDs can be advantageous provided fiscal prudence is maintained.

\section{v. Conclusion}

With the advent of market reforms in the formerly-planned economies, financial markets have been substantially liberalized and restrictions on foreign currency holdings significantly relaxed. As a result, several of the transition economies have undergone a rapid process of dollarization. This paper has taken a first look at the evidence on dollarization for 15 economies in transition. The data show that, starting from negligible levels of dollarization (with the notable exceptions of Poland and the former Yugoslavia), the ratio of foreign currency deposits to broad money (including foreign currency deposits) reached between 30 and 60 percent in most countries during 1992-1993. Dollarization has become particularly important in those countries--such as Russia and Romania--where the combination of high inflation and widespread regulations on interest rates has rendered real returns on domestic-currency denominated assets highly unattractive.

1/ It should be noticed that in Brazil there have typically been restrictions on foreign currency deposits. In the absence of such a sophisticated system of financial indexation, however, the economy would have become informally dollarized and there would have been massive capital flight.

2/ See Rodriguez (1991) and Calvo and Végh (1995a). 
The evidence also suggests that dollarization has fallen quite substantially in those economies--such as Estonia, Lithuania, Mongolia, and Poland--which have successfully stabilized and have allowed marketforces to play a bigger role in determining nominal interest rates. Since dollarization reflects mainly portfolio considerations, both lower inflation and higher nominal interest rates increase real returns on domestic-currency deposits, thus reducing the attractiveness of foreign currency deposits. Naturally, in any economy substantially integrated with world capital markets, some degree of dollarization should still be expected--even in the presence of competitive real returns on domestic assets--as a reflection of an optimal degree of portfolio diversification.

While the twin phenomena of dollarization and capital inflows pose some important challenges to macroeconomic policy--as discussed in this paper and in Calvo, Sahay, and vegh (1995)--there can be little doubt that, on the whole, they should be viewed as a welcome development as they expand the public's portfolio choices, increase firms' credit availability, and provide needed capital for investment. 


\section{References}

Agénor, Pierre-Richard, and Mohsin S. Khan, "Foreign Currency Deposits and the Demand for Money in Developing Countries," Working Paper $92 / 1$ (IMF, 1992).

Aghevli, Bijan, Eduardo Borensztein, and Tessa van der Willigen, Stabilization and Structural Reform in the Czech and Slovak Federal Republic: First Stage, Occasional Paper 92 (IMF, 1992).

Benett, Adam G.G., "The Operation of the Estonian Currency Board," IMF Staff Papers: Vol. 40 (1993), pp. 451-470.

Blejer, Mario I., Mauro Mecagni, Ratna Sahay, Richard Hides, Barry Johnston, Piroska Nagy, and Roy Pepper, Albania: From Isolation Toward Reform: Occasional Paper 98 (IMF, 1922).

Boote, Anthony R. and Janos Somogyi, Economic Reform in Hungary Since 1968 , Occasional Paper 83 (IMF, 1991).

Bufman, Gil and Leonardo Leiderman, "Currency Substitution under Nonexpected Utility: Some Empirical Evidence," Journal of Money. Credit, and Banking, Vol. 25 (1993), pp. 320-325.

Clements Benedict, and Gerd Schwartz, "Currency Substitution: The Recent Experience with Bolivia," World Development. Vol. 21, No. 11 (1993), pp. 1883-1893.

Calvo Guillermo A. and Carlos Rodriguez, "A Model of Exchange Rate Determination under Currency Substitution and Rational Expectations," Journal of Political Economy. Vol. 85 (1977), pp. 617-625.

, Ratna Sahay, and Carlos A. Vegh, "Capital Flows in Central and Eastern Europe: Issues and Policy Options," IMF Working Paper 95/57.

, and Carlos A. V́egh, "Currency Substitution in Developing Countries: An Introduction," Revista de Analisis Economico. Vol. 7 (1992), pp. 3-27. Also issued as IMF Working Paper 92/40 (1992).

, and Carlos A. V́egh, "Fighting Inflation with High Interest Rates: The Small Open Economy Case under Flexible Prices," Journal of Money. Credit, and Banking. Vol. 27 (1995a), pp, 49-66.

, and Carlos A. V́egh, "From Currency Substitution to Dollarization and Beyond: Analytical and Policy Issues," in Guillermo A. Calvo, Essays on Money. Inflation, and Output (Cambridge, Mass.: MIT Press, 1995b, forthcoming).

Demekas, Dimitri G., and Mohsin Khan, The Romanian Economic Reform Program, Occasional Paper No. 89 (IMF, 1991). 
Dornbusch, Rudiger, Federico Sturzenegger, and Holger Wolf, "Extreme Inflation: Dynamics and Stabilization," Brooking_Papers on Economic Activity: (2: 1990), pp. 2-84.

, and Alejandro Reynoso, "Financial Factors in Economic Development," NBER Working Paper 2889 (1989).

El-Erian, Mob aimed A. , "Currency Substitution in Egypt and the Yemen Arab Republic, IMF Staff Papers. Vol. 12 (1988), pp. 85-103.

Giovannini, Alberto and Bart Turtelboom, "Currency Substitution," in Frederick van der Ploeg, ed., Handbook of International Macroeconomics (Cambridge, Massachusetts: Blackwell Publishers), pp, 390-436.

Guidotti, Pablo E., and Carlos A. Rodriguez, "Dollarization in Latin America: Gresham's Law in Reverse," IMF Staff Papers. Vol. 39 (1992), pp. 518-544.

Friedman, Benjamin M. , "Targets and Instruments of Monetary Policy" in Handbook of Monetary Economics: Volume II (Amsterdam: North Holland (1990), pp. 1185-1230.

Hoffmaister, Alex and Carlos A. Végh, "Disinflation and the Recession-NowVersus-Recession-Later Hypothesis: Evidence from Uruguay," unpublished manuscript (IMF, 1994).

Kamin, Steven B, and Neil Ericsson, "Dollarization in Argentina," International Finance Discussion Papers No. 460 (Board of Governors of the Federal Reserve System, 1993). ,

Kareken, John and Neil Wallace, "On the Indeterminacy of Equilibrium Exchange Rates," Quarterly Journal of Economics. Vol. 96 (1981), pp. 207-222.

Kiguel, Miguel and Nissan Llviatan, "Stopping Inflation: The Experience of Latin America and Israel and the Implications for Central and Eastern Europe," in Vittorio Corbo, Fabrizio Coricelli, and Jan Bossak, eds., Reforming Central and Eastern European Economies (World Bank, 1991).

Morsink, James, "Dollarization in Mongolia," mimeo (IMF, 1994).

Mueller, Johannes, "Dollarization in Lebanon," IMF Working Paper 94/129 (1994).

Pérez, Lorenzo, "The Implications of Currency Substitution Experiences in Latin America and in Europe for Cuba," mimeo (IMF, 1994).

Rodriguez, Carlos A., "Financial Reform and Macroeconomic Developments in Argentina, Chile, and Uruguay during the Decade of the 80s," mimeo CEMA, Buenos Aires, 1991). 
Sachs, Jeffrey, "The Bolivian Hyperinflation and Stabilization," NBER Working Paper No. 2073 (1986).

Sahay, Ratna, and Carlos A. Végh, "Inflation and Stabilization in Transition Economies: A Comparison with Market Economies," IMF Working Paper 95/8 (1995).

Savastano, Miguel A., "The Pattern of Currency Substitution in Latin America: An Overview," Revlsta de Analisis_Economica. Vol. 7 (1992), pp. 29-72.

Sturzenegger, Federico, "Understanding the Welfare Effects of Dollarization," mimeo (UCLA, 1993).

Thomas, I,R., "Portfolio Theory and Currency Substitution," Journal of Money. Credit, and Banking. Vol. 17 (1985), pp. 347-357.

Uribe, Martin, "Hysteresis in a Simple Model of Currency Substitution," mimeo (University of Chicago, 1994).

Végh, Carlos A., "The Optimal Inflation Tax in the Presence of Currency Substitution," Journal of Monetary Economics, Vol. 24 (1989), pp. 139-146. 